\title{
Sodium Is Not Required for Chloride Efflux via Chloride/Bicarbonate Exchanger from Rat Thymic Lymphocytes
}

\author{
Donatas Stakišaitis, ${ }^{1,2}$ Vaidevutis Meilus, ${ }^{1}$ Alfonsas Juška, ${ }^{1}$ \\ Paulius Matusevičius, ${ }^{3}$ and Janina Didžiapetriene ${ }^{1}$ \\ ${ }^{1}$ Institute of Oncology, Vilnius University, Baublio Street 3b, 08660 Vilnius, Lithuania \\ ${ }^{2}$ Mykolas Romeris University, Ateities Street 21, 08303 Vilnius, Lithuania \\ ${ }^{3}$ Lithuanian University of Health Sciences, Veterinary Academy, Mickevičiaus Street 9, 44307 Kaunas, Lithuania \\ Correspondence should be addressed to Donatas Stakišaitis; dstakisaitis@yahoo.com
}

Received 8 May 2014; Accepted 20 May 2014; Published 9 June 2014

Academic Editor: Yoshinori Marunaka

Copyright (C) 2014 Donatas Stakišaitis et al. This is an open access article distributed under the Creative Commons Attribution License, which permits unrestricted use, distribution, and reproduction in any medium, provided the original work is properly cited.

Sodium-dependent $\mathrm{Cl}^{-} / \mathrm{HCO}_{3}{ }^{-}$exchanger acts as a chloride $\left(\mathrm{Cl}^{-}\right)$efflux in lymphocytes. Its functional characterization had been described when $\mathrm{Cl}^{-}$efflux was measured upon substituting extracellular sodium ( $\mathrm{Na}^{+}$) by N-methyl-D-glucamine (NMDG). For $\mathrm{Na}^{+}$and $\mathrm{Cl}^{-}$substitution, we have used D-mannitol or NMDG. Thymocytes of male Wistar rats aged 7-9 weeks were used and intracellular $\mathrm{Cl}^{-}$was measured by spectrofluorimetry using MQAE dye in bicarbonate buffers. Chloride efflux was measured in a $\mathrm{Cl}^{-}$-free buffer $\left(\mathrm{Cl}^{-}\right.$substituted with isethionate acid) and in $\mathrm{Na}^{+}$and $\mathrm{Cl}^{-}$-free buffer with D-mannitol or with NMDG. The data have shown that $\mathrm{Cl}^{-}$efflux is mediated in the absence of $\mathrm{Na}^{+}$in a solution containing D-mannitol and is inhibited by $\mathrm{H}_{2} \mathrm{DIDS}$. Mathematical modelling has shown that $\mathrm{Cl}^{-}$efflux mathematical model parameters (relative membrane permeability, relative rate of exchanger transition, and exchanger efficacy) were the same in control and in the medium in which $\mathrm{Na}^{+}$had been substituted by D-mannitol. The net $\mathrm{Cl}^{-}$efflux was completely blocked in the NMDG buffer. The same blockage of $\mathrm{Cl}^{-}$efflux was caused by $\mathrm{H}_{2}$ DIDS. The study results allow concluding that $\mathrm{Na}^{+}$is not required for $\mathrm{Cl}^{-}$efflux via $\mathrm{Cl}^{-} / \mathrm{HCO}_{3}^{-}$exchanger. NMDG in buffers cannot be used for substituting $\mathrm{Na}^{+}$because NMDG inhibits the exchanger.

\section{Introduction}

Lymphocyte intracellular chloride $\left(\left[\mathrm{Cl}^{-}\right]_{i}\right)$ is regulated by the relative activities of plasma membrane chloride $\left(\mathrm{Cl}^{-}\right)$influx and $\mathrm{Cl}^{-}$efflux pathways [1]. Literature data show that rat thymocytes (thymic lymphocytes) possess $\mathrm{Na}$-dependent and Na-independent $\mathrm{Cl}^{-} / \mathrm{HCO}_{3}{ }^{-}$exchangers ([1, 2]; Figure 1). So far, two classes of $\mathrm{Cl}^{-} / \mathrm{HCO}_{3}{ }^{-}$exchangers have been described in mammalian cells. The first-the band 3 family of $\mathrm{Cl}^{-} / \mathrm{HCO}_{3}{ }^{-}$exchanger (AE1, AE2, and AE3 isoforms)-is $\mathrm{Na}$-independent [3]. It acts as a $\mathrm{Cl}^{-}$influx mechanism (the intracellular $\mathrm{HCO}_{3}{ }^{-}$exchanger for extracellular $\mathrm{Cl}^{-}$) $[4,5]$. The second exchanger has been identified as a $\mathrm{Na}$-dependent $\mathrm{Cl}^{-} / \mathrm{HCO}_{3}{ }^{-}$exchanger acting as a $\mathrm{Cl}^{-}$efflux mechanism $[1,2,4]$. The description of functional characterization of
Na-dependent $\mathrm{Cl}^{-} / \mathrm{HCO}_{3}{ }^{-}$exchangers in lymphocytes has been limited when evaluating fluorimetric intracellular $\mathrm{pH}$ change measurements [2]. Later, the same method was used while repeatedly evaluating fluorimetric $\left[\mathrm{Cl}^{-}\right]_{i}$ data [1] in the way the $\mathrm{Na}$-dependent $\mathrm{Cl}^{-} / \mathrm{HCO}_{3}{ }^{-}$exchanger was described after cell $\mathrm{Cl}^{-}$efflux had been measured upon substituting extracellular $\mathrm{Na}^{+}$by $\mathrm{N}$-methyl-D-glucamine (NMDG).

In the present study, we examined $\mathrm{Cl}^{-}$efflux by using the fluorimetric $\mathrm{Cl}^{-}$dye N(ethoxycarbonylmethyl)-6-methoxyquinolinium bromide (MQAE) to determine rat thymocyte $\left[\mathrm{Cl}^{-}\right]_{i}$ changes during acute exposure to $\mathrm{Cl}^{-}$-free media. For $\mathrm{Na}^{+}$and $\mathrm{Cl}^{-}$substitution, we used D-mannitol or NMDG. We show that $\mathrm{Cl}^{-}$efflux is mediated in the absence of $\mathrm{Na}^{+}$in a solution containing $\mathrm{D}$-mannitol and is totally inhibited by $\mathrm{H}_{2}$ DIDS. 


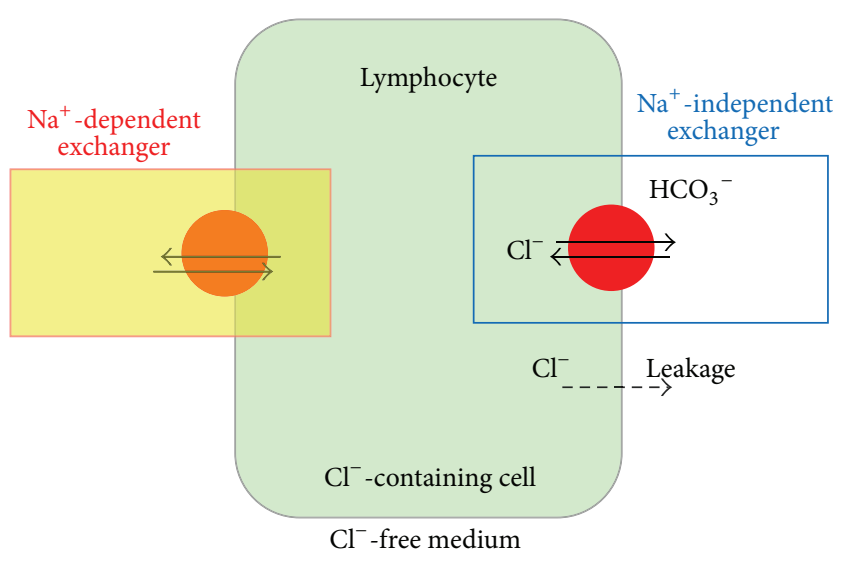

FIGURE 1: Schematic representation of a thymocyte contained in chloride-free and either sodium containing or sodium-free medium and pathways and mechanisms of chloride fluxes. Only the pathways and mechanisms of the main concern considered relevant for the present investigation are depicted here. The continuous arrows symbolize the controlled ion flux and the broken one, the uncontrolled flux (leakage), of the ions from the cell. Chloride fluxes (and its efflux) are believed to depend on sodium presence in the medium, that is, on the exchangers of both types $\left(\mathrm{Na}^{+}\right.$-dependent and $\mathrm{Na}^{+}$independent) depicted on both sides of the cell. No contribution of the sodium-dependent exchanger to chloride efflux from rat thymocytes could be observed in this investigation.

\section{Material and Methods}

Thymocytes were isolated from the glandula thymus of male Wistar rats aged 7-9 weeks. Experiments were performed in compliance with the relevant laws and institutional guidelines. The permissions of the State Food and Veterinary Service of Lithuania to use experimental animals for research were obtained (25/07/2013). All bicarbonatecontaining buffers were preequilibrated with $5 \% \mathrm{CO}_{2}, 20 \%$ $\mathrm{O}_{2}$, and $75 \% \mathrm{~N}_{2}$ and were kept at $37^{\circ} \mathrm{C}$. The composition of buffers is as follows: a standard $100 \% \mathrm{Cl}^{-}$buffer (solution 1), a $\mathrm{Cl}^{-}$-free buffer (solution 2), a Na${ }^{+}$- and $\mathrm{Cl}^{-}$-free buffer with D-mannitol (solution 3), and $\mathrm{Na}^{+}-$and $\mathrm{Cl}^{-}$-free buffer containing N-methyl-D-glucamine (solution 4) (Table 1).

$\left[\mathrm{Cl}^{-}\right]_{i}$ was measured by the spectrofluorimetric method using MQAE dye as described [1]. Chloride efflux in control thymocytes was measured $(n=8)$ in a buffer in which $\mathrm{Cl}^{-}$ had been substituted with isethionate acid (solution 2), in a $\mathrm{Na}^{+}$- and $\mathrm{Cl}^{-}$-free buffer containing D-mannitol $(n=8$; solution 3), in thymocytes pretreated with $125 \mu \mathrm{M} \mathrm{H}_{2}$ DIDS in a $\mathrm{Na}^{+}$- and $\mathrm{Cl}^{-}$-free buffer containing D-mannitol $(n=$ 4) and in a buffer containing NMDG $(n=4$; solution 4). The buffer isotonicity was calculated according to $\mathrm{NaCl}$ equivalents [6]. Fluorescence measurements were performed with a Perkin Elmer 50B spectrofluorometer (excitation wavelength $352 \mathrm{~nm}$ and emission wavelength $450 \mathrm{~nm}) .\left[\mathrm{Cl}^{-}\right]_{i}$ was calculated by using a procedure as described $[1,7]$. MQAE, $\mathrm{H}_{2}$ DIDS, and all other chemicals were purchased from Sigma, Sigma-Aldrich, Fluka, AppliChem, BioEKSMA.

For modelling and model fitting, standard software was used. The models are based on the scheme presented in
Figure 1. The systems of simple differential equations were solved with Maple. Data processing was carried out using Microsoft Excel [8].

\section{Results}

3.1. General Considerations, Supposed Relationships, and Modeling. The $\left[\mathrm{Cl}^{-}\right]_{i}$ level of thymocytes after their acute exposure to different buffers shows no statistically significant difference $(P>0.05): 22.6 \pm 2.7 \mathrm{mM}$ in solution 2 (see Table 1), $22.1 \pm 3.2$ in the same solution pretreated with $\mathrm{H}_{2}$ DIDS, $21.0 \pm 2.9$ in solution $3,21.5 \pm 2.4$ in the same solution pretreated with $\mathrm{H}_{2}$ DIDS, and $19.7 \pm 1.3 \mathrm{mM}$ with NMDG (solution 4). In the presence of $\mathrm{Cl}^{-}$and $\mathrm{HCO}_{3}{ }^{-}$in thymocytes, acute exposure of the cells to an isotonic $\mathrm{Cl}^{-}$-free solution and $\mathrm{Na}^{+}$- and $\mathrm{Cl}^{-}$-free solutions with a D-mannitol substitute resulted in a rapid decline of $\left[\mathrm{Cl}^{-}\right]_{i}$.

The current understanding of the mechanisms of $\mathrm{Cl}^{-}$ efflux from thymocytes is presented in the scheme depicted in Figure 1. The efflux from the cells in which the activity of the exchanger is inhibited has to be assigned to a noncontrollable leakage of chloride anions through the membrane. The rate of the leakage $\left(F_{\text {leak }}\right)$, presumably, can be expressed as follows:

$$
F_{\text {leak }}=-\alpha y \text {, }
$$

where $\alpha$ is relative permeability of cellular membrane and $y$ is transmembrane difference of $\mathrm{Cl}^{-}$concentration or just $\mathrm{Cl}^{-}$ concentration in the cytoplasm (if the medium is $\mathrm{Cl}^{-}$-free). The solution of the above equation is

$$
y=y_{0} \exp (-\alpha t),
$$

$y_{0}$ being initial $\mathrm{Cl}^{-}$concentration in the cytoplasm. The model is depicted in Figure 2.

Experimental data of cytoplasmic $\mathrm{Cl}^{-}$concentrations in the absence of $\mathrm{Cl}^{-} / \mathrm{HCO}_{3}{ }^{-}$exchange inhibition (Figure 2) suggest the decline to proceed with the relative rate different from constant. At the beginning it is slow, then fast, and slow again, keeping in mind that the observed decline in $\mathrm{Cl}^{-}$ concentration results from both noncontrollable $\mathrm{Cl}^{-}$leakage via the cellular membrane and its efflux via the exchanger. The total efflux rate can be presented as follows [8]:

$$
\frac{\mathrm{d} y}{\mathrm{~d} t}=-\alpha y-A \frac{\lambda \mu}{\lambda-\mu}(\exp (-\mu t)-\exp (-\lambda t)),
$$

where $A$ symbolizes the efficacy of the exchanger and $\lambda$ and $\mu$ stand for relative rates of rise and decline of its activity, the parameters $\lambda$ and $\mu$ being interchangeable. The solution of the above equation is

$$
\begin{aligned}
y= & y_{0} \exp (-\alpha t)-A \exp (-\alpha t) \lambda \mu \\
\times & \times\left(\frac{(\mu-\alpha) \exp (-(\lambda-\alpha) t)}{(\lambda-\alpha)(\mu-\alpha)(\lambda-\mu)}\right. \\
& \left.\quad-\frac{(\lambda-\alpha) \exp (-(\mu-\alpha) t)+(\lambda-\mu)}{(\lambda-\alpha)(\mu-\alpha)(\lambda-\mu)}\right) .
\end{aligned}
$$


TABLE 1: Solution compositions ( $\mathrm{mM})$.

\begin{tabular}{|c|c|c|c|c|}
\hline Ingredient & $\begin{array}{l}\text { Solution 1 } \\
\left(100 \% \mathrm{Cl}^{-}\right)\end{array}$ & $\begin{array}{l}\text { Solution } 2 \\
\left(\mathrm{Cl}^{-} \text {-free }\right)\end{array}$ & $\begin{array}{c}\text { Solution } 3 \\
\left(\mathrm{Cl}^{-}-\text {and } \mathrm{Na}^{+} \text {-free }\right. \\
\text { with } \mathrm{D} \text {-mannitol })\end{array}$ & $\begin{array}{c}\text { Solution } 4 \\
\left(\mathrm{Cl}^{-} \text {- and } \mathrm{Na}^{+} \text {-free }\right. \\
\text { with } \mathrm{NMDG})\end{array}$ \\
\hline Glucose & 5 & 5 & 5 & 5 \\
\hline HEPES & 5 & 5 & 5 & 5 \\
\hline $\mathrm{MgSO}_{4}$ & 0.8 & 0.8 & 0.8 & 0.8 \\
\hline $\mathrm{NaH}_{2} \mathrm{PO}_{4}$ & 1 & 1 & 0 & 0 \\
\hline $\mathrm{KH}_{2} \mathrm{PO}_{4}$ & 0 & 0 & 1 & 1 \\
\hline Ca acetate & 1.8 & 1.8 & 0 & 0 \\
\hline $\mathrm{NaCl}$ & 96 & 0 & 0 & 0 \\
\hline $\mathrm{Na}$ isethionate & 16.4 & 117.3 & 0 & 0 \\
\hline D-mannitol & 0 & 0 & 185 & 0 \\
\hline $\mathrm{KCl}$ & 5.3 & 0 & 0 & 0 \\
\hline $\mathrm{N}$-methyl-D-glucamine & 0 & 0 & 0 & 185 \\
\hline K gluconate & 0 & 0 & 4.3 & 0 \\
\hline $\mathrm{KHCO}_{3}$ & 0 & 5.3 & 0 & 4.3 \\
\hline $\mathrm{NaHCO}_{3}$ & 22 & 16.7 & 0 & 0 \\
\hline Choline $\mathrm{HCO}_{3}$ & 0 & 0 & 22 & 22 \\
\hline
\end{tabular}

TABLE 2: Conditions of the experiments and model parameters estimated by fitting (2) and (4) to experimental data.

\begin{tabular}{|c|c|c|c|}
\hline \multirow[b]{2}{*}{ Parameter } & \multirow[b]{2}{*}{ Notation } & \multicolumn{2}{|c|}{ Estimate } \\
\hline & & $\begin{array}{l}\mathrm{Na}^{+} \text {-containing } \\
\text { medium (solution 2) }\end{array}$ & $\begin{array}{c}\mathrm{Na}^{+} \text {-free medium } \\
\quad(\text { solution } 3)\end{array}$ \\
\hline Initial chloride concentration in cytoplasm, $\mathrm{mM}$ & $y_{\text {cytoplasm }}$ & 22.6 & 21.0 \\
\hline Relative membrane permeability, $\mathrm{s}^{-1}$ & $\alpha$ & 0.000533 & 0.000774 \\
\hline A rate constant of the exchanger transition, $\mathrm{s}^{-1}$ & $\lambda$ & 0.000547 & 0.00547 \\
\hline Another rate constant of the exchanger transition, $\mathrm{s}^{-1}$ & $\mu$ & 0.0169 & 0.0169 \\
\hline Exchanger efficacy, mM & $A$ & 12.1 & 12.2 \\
\hline
\end{tabular}

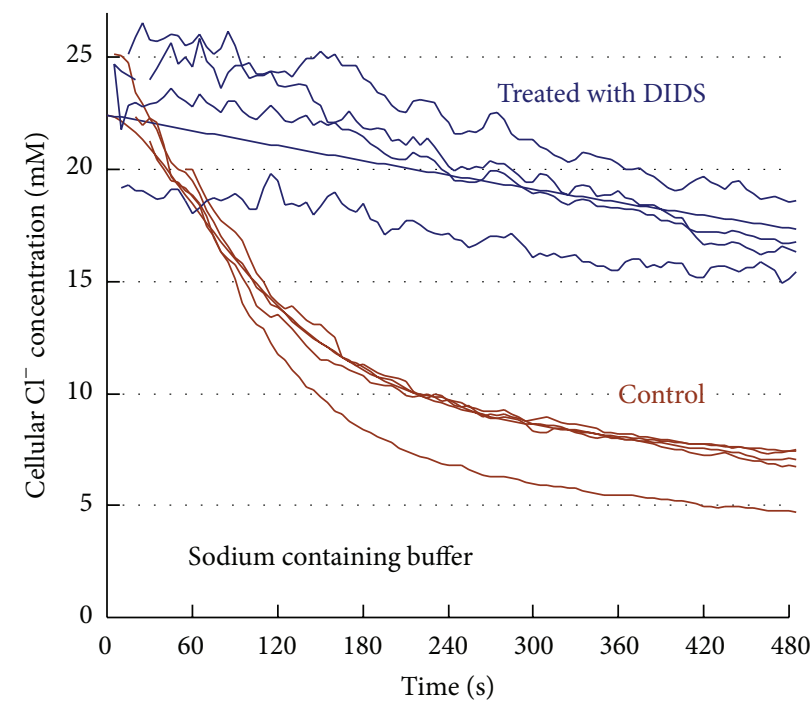

(a)

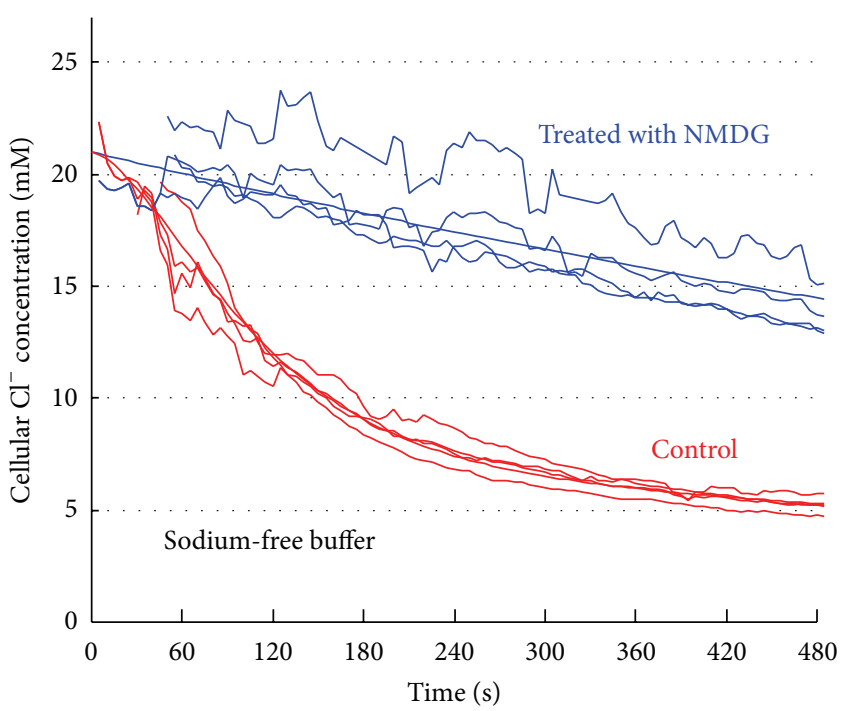

(b)

FIGURE 2: Chloride efflux from thymocytes (treated either with $\mathrm{H}_{2}$ DIDS $(n=4)$ or with NMDG $\left.(n=4)\right)$ into chloride-free, bicarbonatecontaining, and either sodium-containing or sodium-free medium. The smooth curves correspond to model (2) (noncontrollable chloride efflux) or model (4) (taking into account the contribution of the exchanger) with the parameter values presented in Table 2 . The controls were $\mathrm{Na}$ isethionate (a) and D-mannitol (b). The data (zigzagged lines) are representative of $n=8$ (a) and $n=8$ experiments (b). 
3.2. Comparison of Models and Experimental Data. The data together with the models are presented in Figure 2. The models seem quite acceptable suggesting the plausibility of the initial assumptions; together with the parameters contained in Table 2 they are discussed in detail in the next section.

\section{Discussion}

It is commonly accepted that in rat thymocytes the intracellular $\mathrm{Cl}^{-}$level is regulated by $\mathrm{Na}$-independent and $\mathrm{Na}-$ dependent $\mathrm{Cl}^{-} / \mathrm{HCO}_{3}{ }^{-}$exchangers and $\mathrm{Na}-\mathrm{K}-2 \mathrm{Cl}$ cotransporter $[1,2]$. Two classes of $\mathrm{Cl}^{-} / \mathrm{HCO}_{3}{ }^{-}$exchangers related to $\left[\mathrm{Cl}^{-}\right]_{i}$ level regulation were identified in mammalian cells: band 3 family (AE1, AE2, and AE3) was found to be Na-independent [3]. It normally acts as a $\mathrm{Cl}^{-}$influx mechanism $[2,9]$. Lymphocytes express the AE2 isoform which shows a lower affinity for DIDS than does AE1 [4, 9, 10]. The $\mathrm{Cl}^{-} / \mathrm{HCO}_{3}{ }^{-}$exchanger, which was described as a $\mathrm{Na}$-dependent $\mathrm{Cl}^{-} / \mathrm{HCO}_{3}{ }^{-}$one, acts as a $\mathrm{Cl}^{-}$efflux mechanism in experiments of external $\mathrm{Cl}^{-}$removal $[2,11]$. The Na-dependent $\mathrm{Cl}^{-} / \mathrm{HCO}_{3}{ }^{-}$exchanger in thymocytes was described when it was evaluated by measuring intracellular $\mathrm{pH}$ changes [2]. Later, this exchanger was evaluated by measuring $\left[\mathrm{Cl}^{-}\right]_{i}$ in the experimental conditions identical to those reported earlier [1]. Evidence for the existence of a Na-dependent $\mathrm{Cl}^{-} / \mathrm{HCO}_{3}{ }^{-}$exchanger comes from studies examining the effects of DIDS and $\mathrm{Na}^{+}$removal on net $\mathrm{Cl}^{-}$ efflux, in which $\mathrm{Na}^{+}$and $\mathrm{Cl}^{-}$were substituted by NMDG. Such experimental data show that the net $\mathrm{Cl}^{-}$efflux is completely blocked by the acute removal of $\mathrm{Na}^{+}$from the external medium, and this fact led to the conclusion that $\mathrm{Cl}^{-} / \mathrm{HCO}_{3}^{-}$ exchange was due to a $\mathrm{Na}$-dependent mechanism. The nature of the "blockade" mechanism is not clear, nor has the Nadependent $\mathrm{Cl}^{-} / \mathrm{HCO}_{3}{ }^{-}$exchanger been isolated and cloned to date.

The study was undertaken to examine the $\mathrm{Na}^{+}$involved in $\mathrm{Cl}^{-}$efflux from rat thymocytes, using another $\mathrm{Cl}^{-}$and $\mathrm{Na}^{+}$substitute D-mannitol. Examination of the $\mathrm{Cl}^{-}$efflux pathway was performed by acutely exposing cells to $\mathrm{Na}-\mathrm{Cl}^{-}$free media and determining changes in the $\left[\mathrm{Cl}^{-}\right]_{i}$ level. The basal $\left[\mathrm{Cl}^{-}\right]_{i}$ level in the study of thymocytes was similar to $\left[\mathrm{Cl}^{-}\right]_{i}$ levels as found by others for different cell types such as rat thymocytes [1], vascular smooth muscle cells $[7,12]$, and astrocytes [13].

In the presence of $\mathrm{Cl}^{-}$and $\mathrm{HCO}_{3}{ }^{-}$in the thymocytes, acute exposure of the cells to an isotonic $\mathrm{Cl}^{-}$-free solution and $\mathrm{Cl}^{-}$- and $\mathrm{Na}^{+}$-free solutions with a D-mannitol substitute resulted in a rapid decline of $\left[\mathrm{Cl}^{-}\right]_{i}$. The parameters of the mathematical model (relative membrane permeability, relative rate of exchanger transition, and exchanger efficacy) show that $\mathrm{Cl}^{-}$efflux in a bicarbonate buffer in which $\mathrm{Cl}^{-}$is substituted with $\mathrm{Na}$ isethionate is the same as in the $\mathrm{Na}^{+}-\mathrm{Cl}^{-}$free buffer in which these ions are substituted isotonically with D-mannitol.

We stress that the buffer for experiments examining $\mathrm{Na}-$ dependent $\mathrm{Cl}^{-}$efflux where $\mathrm{Na}^{+}$and $\mathrm{Cl}^{-}$are substituted by NMDG cannot be used for evaluating $\mathrm{Cl}^{-}$efflux. The NMDG properties listed below should be estimated while investigating a Na-dependent $\mathrm{Cl}^{-} / \mathrm{HCO}_{3}{ }^{-}$exchanger. The use of NMDG to substitute monovalent cations requires $\mathrm{pH}$ adjustment [14-16]. Following the reconstitution with deionised water, the $\mathrm{pH}$ of $185 \mathrm{mM}$ of the NMDG solution was 11.4 due to the alkaline properties of NMDG (its molecule contains a charged methylamine head group responsible for alkalinity), as NMDG has the ionisation equilibrium constant $K_{b}=3.98 \cdot 10^{-5}$ [17]. Adjustment of the $\mathrm{pH}$ of its solution requires large quantities of acids: $125 \mathrm{mM}$ of $\mathrm{H}_{2} \mathrm{SO}_{4}$ has to be added to adjust the $\mathrm{pH}$ of the solution to 7.3. The osmolarity of the solution was $6.2 \mathrm{~atm}$ before $\mathrm{pH}$ adjustment and $17.4 \mathrm{~atm}$ after it (own calculation).

Historically, NMDG has been used for several decades for the substitution of monovalent cations, assuming that it does not cross the cell membrane. However, today our knowledge of NMDG permeability through ion channels has undergone essential changes. NMDG permeation has been reported in ion channels such as ATP-gated P2X [18], epithelial $\mathrm{Ca}^{2+}$ channel ECaC [19], glutamate receptor [20], mechanosensitive channels [21], and mutant $\mathrm{Na}^{+}$channels [22]. Some transient receptor potential family cation channels display partial permeability to NMDG [23]. In the absence of $\mathrm{K}^{+}$, significant NMDG currents were recorded in human kidney cells expressing Kv3.1/Kv3.2b and Kv1.5 R487Y/V channels. Inward currents were much stronger because of the blockade of the outward currents by intracellular $\mathrm{Mg}^{2+}$, resulting in a strong inward rectification [16]. NMDG rapidly blocks $\mathrm{Ca}^{2+}$-activated $\mathrm{K}^{+}$channels from the inside of the membrane [24]. Extracellular NMDG causes a partial block of outward currents in the TRPC3 member of the transient receptor potential family cation channels [25], and the intracellular NMDG modifies the properties of the $\mathrm{Ca}^{2+} \mathrm{L}$-type channel in guinea pig cardiac myocytes by increasing the overall duration of the $\mathrm{Ca}$-dependent slow action potential 6-fold at $0 \mathrm{mV}$ [26]. NMDG increases the intracellular $\mathrm{Ca}^{2+}$ and $\mathrm{K}^{+}$in Ehrlich Lettre ascite cells, changing the intracellular $\mathrm{pH}$ [27].

When using NMDG for $\mathrm{Na}^{+}$substitution, the solution hypertonicity, alkaline features of the substitute, and an additional high concentration of anions appearing after buffer adjustment with acids could change the functioning of the exchanger. AE2 studies have also shown that it is capable of transporting a number of different anions working in a number of different modes of exchange such as $\mathrm{Cl}^{-} / \mathrm{Cl}^{-}$ and sulfate/chloride [28]. Band 3 protein may also be able to exchange $\mathrm{Cl}^{-} / \mathrm{OH}^{-}$[29]; besides, it has been shown to transport sulphate $[30,31]$ and phosphate anions [32].

The study data show that there is no $\mathrm{Cl}^{-}$efflux from thymocytes in a bicarbonate buffer in which $\mathrm{Na}^{+}$and $\mathrm{Cl}^{-}$ are substituted by NMDG. However, $\mathrm{Cl}^{-}$efflux through $\mathrm{Cl}^{-} / \mathrm{HCO}_{3}{ }^{-}$exchanger occurs when the neutral substitute Dmannitol is used instead of NMDG. This means that extracellular $\mathrm{Na}^{+}$is not required for $\mathrm{Cl}^{-}$efflux in rat thymocytes. This could be in agreement with studies indicating that in experimental conditions of external $\mathrm{Cl}^{-}$removal the AE2 antiporter can be reversed; that is, it works at both sides of a lymphocyte membrane $[4,33]$. Pretreatment of cells with DIDS before exposure to a $\mathrm{Cl}^{-}$-free solution inhibited the decline in $\left[\mathrm{Cl}^{-}\right]_{i}$, suggesting that the $\mathrm{Cl}^{-} / \mathrm{HCO}_{3}{ }^{-}$exchange 


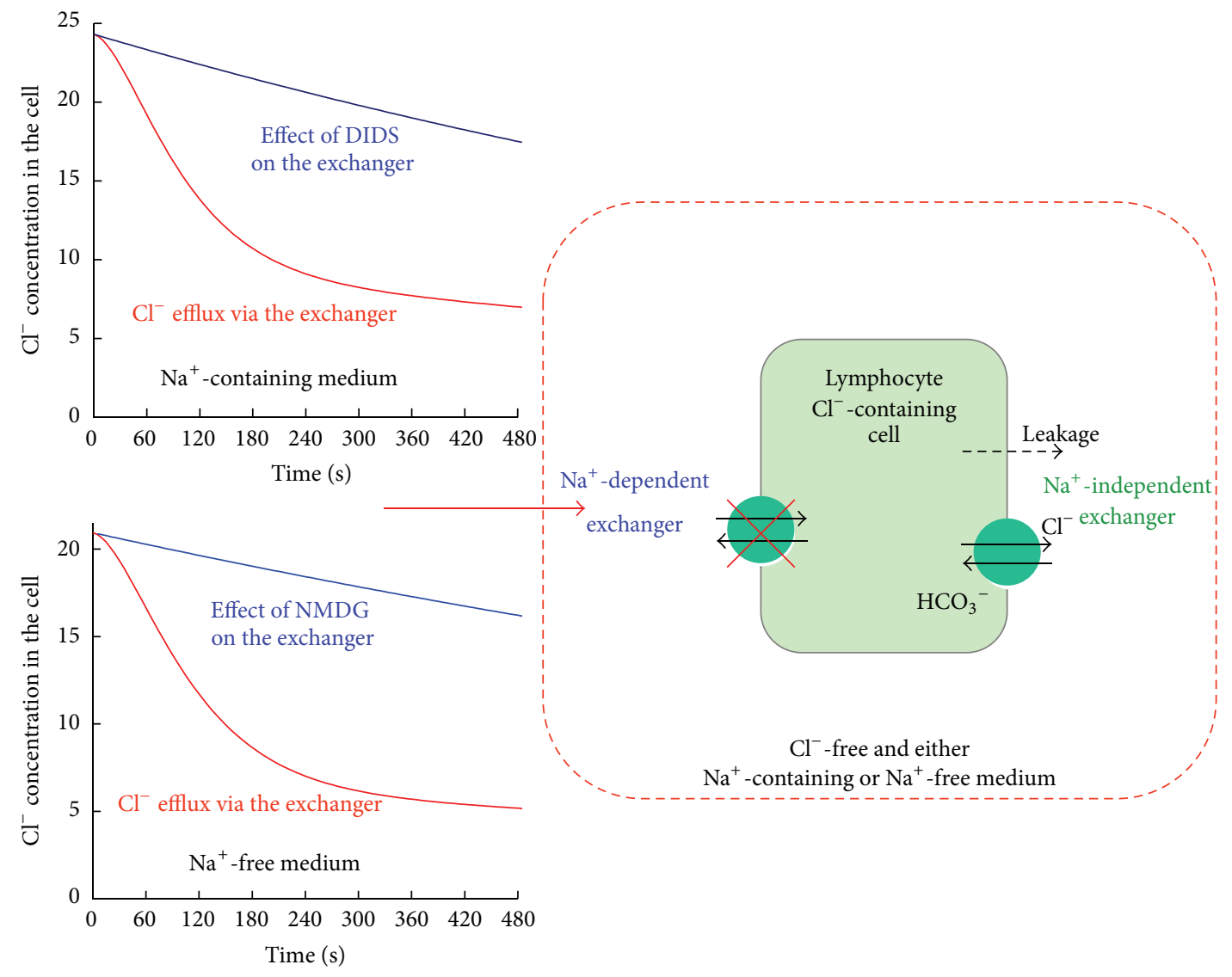

FIgure 3: The summarized results of the $\mathrm{Cl}^{-}$efflux study.

mechanism is responsible for $\mathrm{Cl}^{-}$efflux in these cells. The stilbene compound (DIDS, SITS) binding site is located on the outer surface of the membrane rather than buried within the pocket formed by the tertiary complex of the protein $[34,35]$. No contribution of $\mathrm{Na}$ dependence of $\mathrm{Cl}^{-} / \mathrm{HCO}_{3}{ }^{-}$ exchanger has been observed in the study. The main data of the study are summarized in Figure 3.

Hence, it follows that the presence or absence of $\mathrm{Na}^{+}$ in the extracellular medium is not relevant for $\mathrm{Cl}^{-}$efflux from thymocytes, implying that $\mathrm{Cl}^{-}$efflux in experimental conditions is related to $\mathrm{Cl}^{-} / \mathrm{HCO}_{3}{ }^{-}$exchanger (band 3) in thymocytes. Sodium substitution with NMDG leads to an inhibition of the $\mathrm{Cl}^{-} / \mathrm{HCO}_{3}{ }^{-}$exchanger. The higher estimate of noncontrolled leakage ( $\alpha$, see Table 2$)$ suggests an incomplete inhibition at the NMDG concentration used in the study.

\section{Conclusions}

The main results of this work can be summarized as follows:

(i) $\mathrm{Na}^{+}$is not required for $\mathrm{Cl}^{-}$efflux via $\mathrm{Cl}^{-} / \mathrm{HCO}_{3}{ }^{-}$ exchanger from rat thymocytes;

(ii) no Na-dependent $\mathrm{Cl}^{-} / \mathrm{HCO}_{3}{ }^{-}$exchanger is present in rat thymocytes;

(iii) NMDG leads to exchanger inhibition.

\section{Conflict of Interests}

Authors of this research have no conflict of interests regarding this paper.

\section{Acknowledgment}

This research was funded by Grant no. MIP-12224 of the Research Council of Lithuania.

\section{References}

[1] D. Stakisaitis, M. S. Lapointe, and D. Batlle, "Mechanisms of chloride transport in thymic lymphocytes," The American Journal of Physiology-Renal Physiology, vol. 280, no. 2, pp. F314F324, 2001 .

[2] J. Redon and D. Batlle, "Regulation of intracellular $\mathrm{pH}$ in the spontaneously hypertensive rat. Role of bicarbonate-dependent transporters," Hypertension, vol. 23, no. 4, pp. 503-512, 1994.

[3] S. L. Alper, "Molecular physiology and genetics of $\mathrm{Na}^{+}$independent SLC4 anion exchangers," Journal of Experimental Biology, vol. 212, no. 11, pp. 1672-1683, 2009.

[4] J. J. Garcia-Soto and S. Grinstein, "Determinants of the transmembrane distribution of chloride in rat lymphocytes: role of $\mathrm{Cl}^{-} / \mathrm{HCO}_{3}{ }^{-}$exchange," The American Journal of PhysiologyCell Physiology, vol. 258, no. 6, pp. C1108-C1116, 1990. 
[5] M. M. Kay, C. Cover, and C. H. Vollard, "Human erythroid band 3 "anion exchanger 1" is expressed in transformed lymphocytes," Cellular and molecular biology, vol. 42, no. 7, pp. 945-952, 1996.

[6] M. Windholz, S. Budavari, R. F. Blumetti, and E. S. Otterbein, The Merk Index, Merk, White House Station, NJ, USA, 12th edition, 1996.

[7] C. Koncz and J. T. Daugirdas, "Use of MQAE for measurement of intracellular [Cl-] in cultured aortic smooth muscle cells," The American Journal of Physiology-Heart and Circulatory Physiology, vol. 267, no. 6, pp. H2114-H2123, 1994.

[8] A. Juška, "Dynamics of calcium fluxes in nonexcitable cells: mathematical modeling," The Journal of Membrane Biology, vol. 211, no. 2, pp. 89-99, 2006.

[9] R. R. Kopito, "Molecular biology of the anion exchanger gene family," International Review of Cytology, vol. 123, pp. 177-199, 1990.

[10] B. S. Lee, R. B. Gunn, and R. R. Kopito, "Functional differences among nonerythroid anion exchangers expressed in a transfected human cell line," The Journal of Biological Chemistry, vol. 266, no. 18, pp. 11448-11454, 1991.

[11] M. S. LaPointe and D. Batlle, "Regulation of intracellular $\mathrm{pH}$ and the $\mathrm{Na}^{+} / \mathrm{H}^{+}$antiporter in smooth muscle," in Contemporary Endocrinology, J. R. Sowers and M. W. Totowa, Eds., pp. 301-323, Humana Press, New York, NY, USA, 1996.

[12] J. P. L. Davis, A. R. Chipperfield, and A. A. Harper, "Accumulation of intracellular chloride by $(\mathrm{Na}-\mathrm{K}-\mathrm{Cl})$ co-transport in rat arterial smooth muscle is enhanced in deoxycorticosterone acetate (DOCA)/salt hypertension," Journal of Molecular and Cellular Cardiology, vol. 25, no. 3, pp. 233-237, 1993.

[13] M. O. Bevensee, M. Apkon, and W. F. Boron, "Intracellular $\mathrm{pH}$ regulation in cultured astrocytes from rat hippocampus. II. Electrogenic $\mathrm{Na} / \mathrm{HCO}_{3}$ cotransport," The Journal of General Physiology, vol. 110, no. 4, pp. 467-483, 1997.

[14] H. H. Damkier, C. Aalkjaer, and J. Praetorius, " $\mathrm{Na}^{+}$-dependent $\mathrm{HCO}_{3}{ }^{-}$import by the slc4a10 gene product involves $\mathrm{Cl}^{-}$export," The Journal of Biological Chemistry, vol. 285, no. 35, pp. 2699827007, 2010.

[15] K. J. Buckler, R. D. Vaughan-Jones, C. Peers, and P. C. G. Nye, "Intracellular $\mathrm{pH}$ and its regulation in isolated type I carotid body cells of the neonatal rat," The Journal of Physiology, vol. 436, pp. 107-129, 1991.

[16] Z. Wang, N. C. Wong, Y. Cheng, S. J. Kehl, and D. Fedida, "Control of voltage-gated $\mathrm{K}^{+}$channel permeability to $\mathrm{NMDG}^{+}$ by a residue at the outer pore," The Journal of General Physiology, vol. 133, no. 4, pp. 361-374, 2009.

[17] D. R. Linde, Ed., CRC Handbook of Chemistry and Physics, Internet Version, CRC Press, Boca Raton, Fla, USA, 2005, http:// www.hbcpnetbase.com.

[18] W. Ma, A. Korngreen, S. Weil et al., "Pore properties and pharmacological features of the P2X receptor channel in airway ciliated cells," The Journal of Physiology, vol. 571, no. 3, pp. 503517, 2006.

[19] B. Nilius, R. Vennekens, J. Prenen, J. G. Hoenderop, R. J. Bindels, and G. Droogmans, "Whole-cell and single channel monovalent cation currents through the novel rabbit epithelial $\mathrm{Ca}^{2+}$ channel ECaC," The Journal of Physiology, vol. 527, no. 2, pp. 239-248, 2000.

[20] S. Ciani, K. Nishikawa, and Y. Kidokoro, "Permeation of organic cations and ammonium through the glutamate receptor channel in Drosophila larval muscle," The Japanese Journal of Physiology, vol. 47, no. 2, pp. 189-198, 1997.
[21] Z. Zhang and C. W. Bourque, "Calcium permeability and flux through osmosensory transduction channels of isolated rat supraoptic nucleus neurons," European Journal of Neuroscience, vol. 23, no. 6, pp. 1491-1500, 2006.

[22] S. Sokolov, T. Scheuer, and W. A. Catterall, "Gating pore current in an inherited ion channelopathy," Nature, vol. 446, no. 7131, pp. 76-78, 2007.

[23] M. Estacion, W. G. Sinkins, S. W. Jones, M. A. B. Applegate, and W. P. Schilling, "Human TRPC6 expressed in HEK 293 cells forms non-selective cation channels with limited $\mathrm{Ca}^{2+}$ permeability," The Journal of Physiology, vol. 572, no. 2, pp. 359377, 2006.

[24] J. D. Lippiat, N. B. Standen, and N. W. Davies, "Block of cloned $\mathrm{BK}(\mathrm{Ca})$ channels (rSlo) expressed in HEK 293 cells by $\mathrm{N}$-methyl D-glucamine," Pflügers Archiv, vol. 436, no. 5, pp. 810-812, 1998.

[25] C. Zitt, A. G. Obukhov, C. Strübing et al., "Expression of TRPC3 in Chinese hamster ovary cells results in calcium-activated cation currents not related to store depletion," The Journal of Cell Biology, vol. 138, no. 6, pp. 1333-1341, 1997.

[26] C. O. Malécot, P. Feindt, and W. Trautwein, "Intracellular $\mathrm{N}$-methyl-D-glucamine modifies the kinetics and voltagedependence of the calcium current in guinea pig ventricular heart cells," Pflügers Archiv, vol. 411, no. 3, pp. 235-242, 1988.

[27] H. T. K. Klausen, S. Preisler, S. F. Pedersen, and E. K. Hoffmann, "Monovalent ions control proliferation of Ehrlich Lettre ascites cells," The American Journal of Physiology-Cell Physiology, vol. 299, no. 3, pp. C714-C725, 2010.

[28] B. D. Humphreys, L. Jiang, M. N. Chernova, and S. L. Alper, "Functional characterization and regulation by $\mathrm{pH}$ of murine AE2 anion exchanger expressed in Xenopus oocytes," The American Journal of Physiology-Cell Physiology, vol. 267, no. 5, pp. C1295-C1307, 1994.

[29] S. R. Hays, " $\mathrm{H}^{+} / \mathrm{OH}^{-} / \mathrm{HCO}_{3}{ }^{-}$transport mechanisms in the inner stripe of the outer medullary collecting duct," Seminars in Nephrology, vol. 11, no. 1, pp. 45-54, 1991.

[30] M. N. Chernova, L. Jiang, M. Crest et al., "Electrogenic sulfate/chloride exchange in Xenopus oocytes mediated by murine AE1 E699Q," The Journal of General Physiology, vol. 109, no. 3, pp. 345-360, 1997.

[31] W. van't Hof, A. Malik, S. Vijayakumar, J. Qiao, J. van Adelsberg, and Q. Al-Awqati, "The effect of apical and basolateral lipids on the function of the band 3 anion exchange protein," The Journal of Cell Biology, vol. 139, no. 4, pp. 941-949, 1997.

[32] W. L. Galanter and R. J. Labotka, "The temperature dependence of human erythrocyte transport of phosphate, phosphite and hypophosphite," Biochimica et Biophysica Acta-Biomembranes, vol. 1027, no. 1, pp. 65-71, 1990.

[33] M. J. Mason, J. D. Smith, J. de Jesus Garcia-Soto, and S. Grinstein, "Internal $\mathrm{pH}$-sensitive site couples $\mathrm{Cl}^{-} / \mathrm{HCO}_{3}{ }^{-}$exchange to $\mathrm{Na}^{+}-\mathrm{H}^{+}$antiport in lymphocytes," The American Journal of Physiology-Cell Physiology, vol. 256, no. 2, part 1, pp. C428C433, 1989.

[34] J. R. Casey and R. A. F. Reithmeier, "Anion exchangers in the red cell and beyond," Biochemistry and Cell Biology, vol. 76, no. 5, pp. 709-713, 1998.

[35] J. M. Salhany, "Mechanism of competition between chloride and stilbenedisulfonates for binding to human erythrocyte band 3 (AE1)," Biochemistry and Cell Biology, vol. 76, no. 5, pp. 715-722, 1998. 

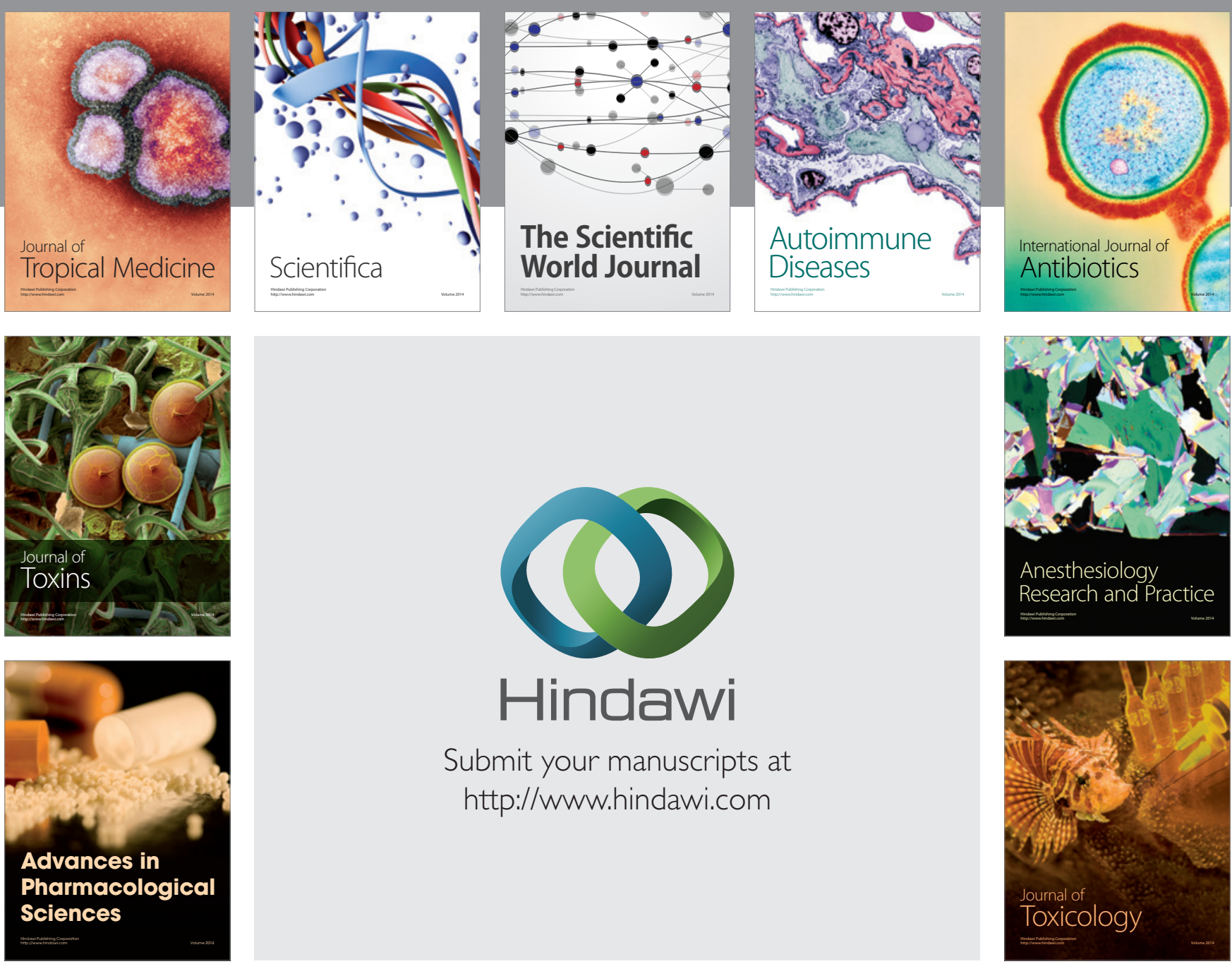

\section{Hindawi}

Submit your manuscripts at

http://www.hindawi.com
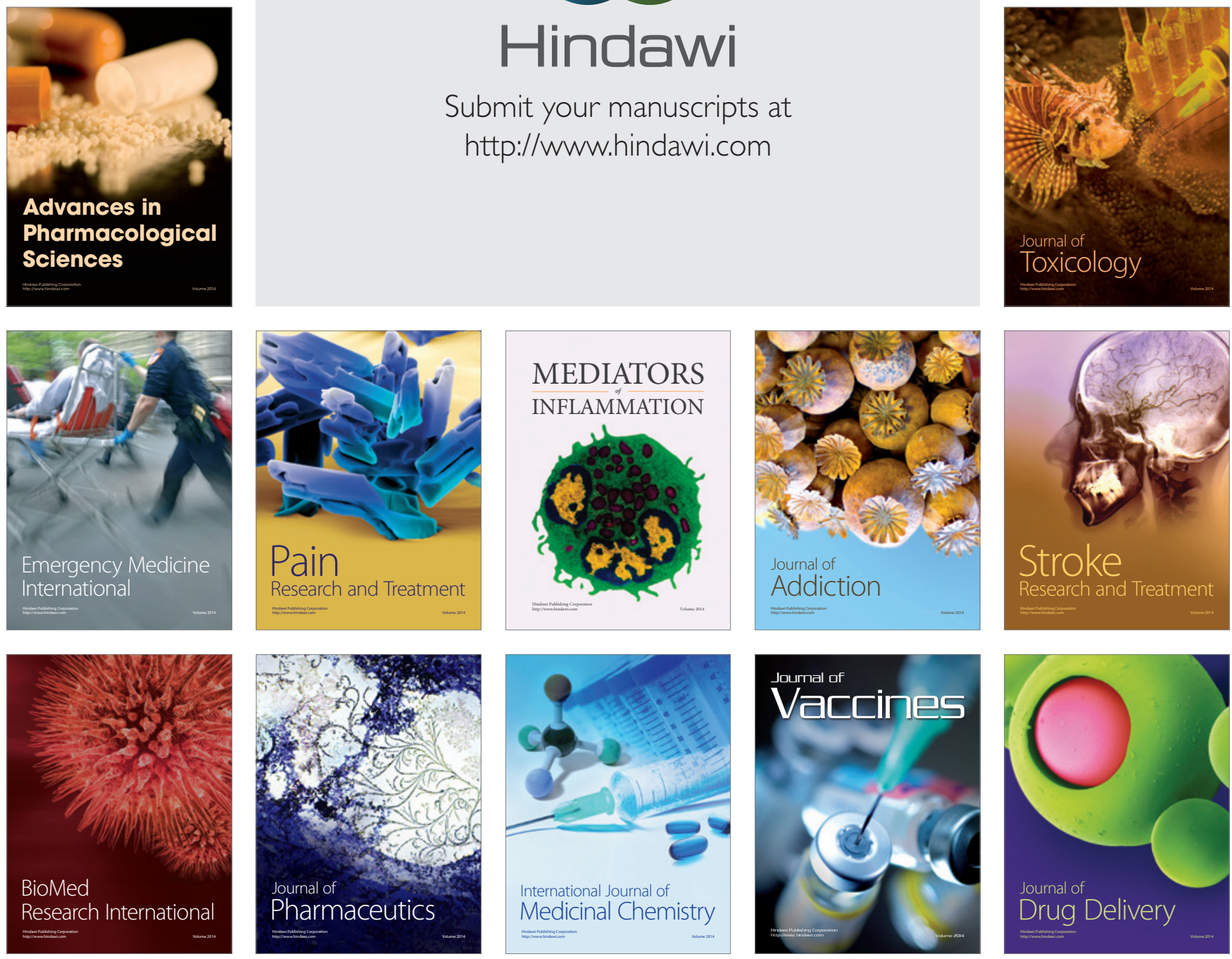